\title{
Evaluating the Main Challenges to a Sustainable Physical Environment in Benin City
}

\author{
Onwuanyi, N. ${ }^{1,}$ and Ojo, E. P. \\ ${ }^{1}$ Department of Estate Management, University of Benin, Benin City, Nigeria \\ ${ }^{2}$ Department of Geomatics, University of Benin, Benin City, Nigeria \\ Corresponding Author: *ndubisi.onwuanyi@ uniben.edu
}

https://doi.org/10.36263/nijest.2021.01.0268

\begin{abstract}
In the shaping of cities as physical environments, planning governance is a principal factor which has sustainability implications for the entire urban system. This suggests that planning governance is a factor which has the potential to contribute to the occurrence of environmental challenges as well their resolution. Nigeria's cities are facing many environmental challenges which constitute threats to sustainable development. This paper examines the main challenges to the development of a sustainable physical environment in Benin City, Nigeria's ninth largest urban centre by population. Relying on archival records and observation, the study evaluates the city's major physical environmental problems and their connection with planning governance; and thereafter, undertakes a comparison of planning governance features in the city with practice in the now sustainable, but once unsustainable environment of London City. The findings are that planning governance exerts a critical influence on the sustainable urban physical environment as in London City; that Benin City's weak planning governance (as manifested by the absence of a master plan, inadequate personnel and equipment, a low public awareness of planning laws, a low level of compliance and a general lack of enforcement) is contributory to the emergence and subsistence of its environmental challenges. The conclusion is that the subsisting environmental challenges of Benin City are rooted in planning governance which, as presently run, lacks the capacity to achieve a sustainable physical environment. It is recommended that the city be re-directed to a trajectory of sustainable physical development through sweeping changes in planning governance and public enlightenment.
\end{abstract}

Keywords: Benin City, Environmental challenges, Physical planning, Sustainable development

\subsection{Introduction}

Human settlements are physical spaces which have been adapted from their natural state. According to Williams (2014) the "urban form is the physical characteristics that make up built-up areas, including the shape, size, density and configuration of settlements". This form is produced by a process which involves changes to terrain and morphology. The urban physical form is created for the provision of space for living, working and recreation (Lohmann, 2006) for which purposes all urban land needs must be accommodated as a cardinal principle of planning design(Keeble,1982). These needs are arranged to achieve complementarity, the separation of incompatible land uses and allowances made for the effect of topography and ecology on the urban form (Keeble, 1982). Urban infrastructure constitutes the physical and related structures needed for functioning of the urban area. It energises the urban form, provides the means of movement of people, information and goods and services. According to Onwuanyi (2020), a city's infrastructure usually comes in two broad forms: the grey (or built) and the green (or planted). Onwuanyi (2020) further states that the former mainly constitute constructed facilities whilst the latter consists of trees, gardens, parks, urban forests and the like. The physical structure of a city, which can be perceived from its layout, reveals the composition of land uses, the space provision for various needs, the pattern of arrangement of land uses, accessibility, aesthetics and physical and ecological constraints imposed on the urban form (Keeble, 1982). The land use pattern particularly influences the quality of the physical environment and its capacity to sustain human activities which, if uncontrolled or unmonitored tend to produce 
environmental stresses. These problems come in dimensions which can be seen, heard, felt, and perceived.

Human activities, according to the United Nations (2015), have the potential to impact negatively upon the environment by reducing its quality and depleting resources. Undoubtedly, human activities create challenging situations in the sense of difficulties for those who occupy and use the environment. According to Massachusetts Institute of Technology (2000), these difficulties come in the form of damage to the physical environment, mostly caused by other people, and usually with harmful consequences for human welfare, either now or in the future. MIT (2000) further argues that some of these difficulties have the potential to extend beyond the present to future occupiers and users of the environment. Environmental challenges may be defined either in broad or narrow terms, depending on intention and focus. A broad definition of may include virtually all issues which impact both people and environment in an urban area.

Damage to the physical environment mostly comes through anthropogenic activities. These produce nuisance, pollution of the air and water bodies, resource depletion, poor sanitation and waste disposal challenges which are common to Nigeria's urban environments. These are threats to present or future human well-being of humans.

As the world's populations increasingly settle in cities, sustainable urban living has become a topical issue. Sustainable urbanism is an environmental, livelihood and urban concept. It envisions cities which are designed, managed and governed to function on a long-term basis as human habitats. This would necessitate their serving as living, working and recreational spaces where the environment is protected, social development promoted and livelihoods and resources sustained to deliver long-term value for the present and in the future. According to Sharifi (2016), sustainable urbanism is the application of sustainability and resilient principles to the design, planning, and administration/operation of cities. This is tantamount to the application of sustainable development principles to urban environments, that is, development (which) seeks to meet the needs and aspirations of the present without compromising the ability to meet those of the future. UN World Commission on Environment and Development (1987). Fundamental to a sustainable urban environment is sustainable physical planning. This is essentially because sustainable environments are sustainably planned, managed and effectively governed. The importance of sustainable environments is emphasised by the UN Sustainable Development Goals (Global Goals) policy 2015 to 2030.This policy which involves 17 goals and 169 targets dedicates Goal 11 and its 10 targets towards the creation of sustainable cities and communities across the world.

Published research and public commentary suggest that Nigeria's cities, including Benin City, are challenged by physical environmental issues. These findings and observations further suggest the existence of challenges to achieving a sustainable physical environment which is necessary for sustainable urban living, development and management. If Nigeria's rapidly urbanising cities are not developing on a trajectory of sustainable development, it is necessary and important to identify the nature of the challenges; ascertain the prerequisites for a sustainable physical environment; and then consider how these measures may be effectively deployed in the study area. It is argued that cities are governed physical spaces and that their challenges of environment cannot be distanced from governance, particularly planning governance, which has the potential to exert a great influence on the condition and quality of the physical environment. Thus, an enquiry into urban environmental challenges necessarily requires an examination of planning governance standards and performance. It is in these regard that this paper evaluates planning governance in Benin City.

The study identifies the nature and manifestations of extant challenges of the physical environment in Benin City. The state of planning governance in the city is compared with practice in the established and sustainable physical environment of London City. The aim is to find out Benin City's areas of conformance with, or divergence from, the path of sustainable physical development. This is done with the intention of drawing lessons which would advise the best approach to the attainment of a sustainable physical environment in Benin City. 


\subsection{Materials and Methods}

This study relies upon archival records and observation to argue its premise that a nexus exists between planning governance and a sustainable physical environment. These data sources are used to identify the nature and manifestations of environmental challenges in Benin City. Furthermore, the challenges are evaluated in terms of their origins. Thereafter, relevant issues of physical planning in the city are evaluated in order to identify their connection with planning governance. Subsequently, the study further stresses the connection between planning governance and a sustainable physical environment by comparing the study area with London City, using the latter as an example of an environment once characterised by unsustainable development, but which now has a sustainable physical environment.

\subsection{Results}

\subsection{Urban environmental problems of Benin City}

Environmental problems are noticeable by the impacts which they produce. These impacts announce their presence or emergence and the nature of the challenge which they pose or can pose. According to Abdallah (2017) "environmental impacts are changes in the natural or built environment, resulting directly from an activity that can have adverse effects on the air, land, water, fish and wildlife or the inhabitants of the ecosystem". This is mostly the case with the main environmental problems of Benin City as collated from the archives and observation and displayed in Table 1. These environmental issues are described and classified either as managerial or cultural.

Table 1: Existing urban challenges in Benin City

\begin{tabular}{clll}
\hline & Environmental Problem & Managerial & Cultural \\
\cline { 2 - 4 } & $\begin{array}{l}\text { Biodiversity } \\
\text { (parks, gardens, street trees, open spaces) }\end{array}$ & $\begin{array}{l}\text { Planning governance/ } \\
\text { personnel }\end{array}$ & Public Awareness \\
2. & $\begin{array}{l}\text { Waste Dumping(conventional household, industrial } \\
\text { and commercial solid waste, electronic and }\end{array}$ & Operational \\
hazardous waste & Equipment/Facilities & Public Compliance \\
3. & $\begin{array}{l}\text { Refuse Burning(release of chemical pollutants) } \\
\text { Erosion(Soil \& Gully) (absent/inadequate/silted } \\
\text { drainage channels, deforestation) }\end{array}$ & $\begin{array}{l}\text { Enforcement Capacity } \\
\text { Pir \&Noise Pollution(generator noise, incompatible } \\
\text { land uses) }\end{array}$ & Enforcement Capacity \\
\hline
\end{tabular}

Authors' Compilation, 2020

The table shows that the lack of open and green spaces is a managerial (decision-making) issue of the planning process, but it is also cultural in the sense of a lack of public awareness of the benefits (Onwuanyi, 2020), giving rise to indifference. The lack of enforcement and monitoring is associated with poor waste management and refuse-burning. Erosion and flooding are associated with improper waste disposal and the cultural issue of poor construction practices involving an increasing use of paved surfaces which prevent rainwater infiltration, and therefore, exacerbate the problem, particularly where storm water drainage is either absent or inadequate (Effiong and Uzoezie, 2017).

Clearly, these listed problems of the Benin City environment typically arise from anthropogenic behaviour and activities. Thus, the solutions must be sought in the alteration of behaviour and practices. Indeed, at one end, humans are responsible for urban governance whilst at the other humans also are responsible for the how the environment is used. A lack of good policies and a failure to adopt good practices both have the potential to impact the environment. Environmental policies and practices are usually subjected to human control by urban planning, a tool for planned development and urban management which shows concern for health and maintaining well-being through averting diseases and illnesses associated with overcrowding, poor sanitation, and exposure to environmental pollution (Hphp, 2015). The suggestion is that the challenges of the urban physical environment as well as their solutions have a common ground in urban planning. The paper, therefore, proceeds to consider the situation of urban physical planning in Benin City by an evaluation of the urban planning function. This is done by reference to archival records and physical observation. 


\subsection{Situation of urban physical planning in Benin City}

Further evaluations were undertaken in regard to the status of physical planning in Benin City. In Table 2, pertinent issues which relate to the urban planning function are listed. For each of these issues an assessment is made of the present status as revealed by archival records and observation.

Table 2: Evaluation of physical planning administration in Benin City

\begin{tabular}{|c|c|c|}
\hline Physical Planning Issues & Situation & Evidence/Evaluation \\
\hline Planning Administration & $\begin{array}{l}\text { Planning was transferred from } \\
\text { Town/City council to state Authority } \\
\text { in } 1968\end{array}$ & $\begin{array}{l}\text { Planning administration was until } 2016 \\
\text { subsumed under the Ministry of Lands; } \\
\text { confirmed by enquiry (2020) }\end{array}$ \\
\hline Urban Governance & $\begin{array}{l}\text { City Governance was under local } \\
\text { authority, but now under four, plus } \\
\text { the state authority }\end{array}$ & $\begin{array}{l}4 \text { local governments exist in the city } \\
\text { (Constitution of the Federal Republic of } \\
\text { Nigeria (1999, as amended) }\end{array}$ \\
\hline Existence of an Urban Masterplan & Not Available & Braimah (1984); Confirmed by enquiry \\
\hline Existence of a Planning Agency & Available & A fact confirmed by enquiry (2020) \\
\hline $\begin{array}{l}\text { Accessibility of the Planning } \\
\text { Agency }\end{array}$ & $\begin{array}{l}\text { Not very Accessible due to a low } \\
\text { public awareness }\end{array}$ & $\begin{array}{l}\text { Omuta (1988); Omorotionmwan } \\
\text { (2012); Adamolekun et al. (2017) }\end{array}$ \\
\hline Resources of the Planning Agency & Limited(human/equipment) & $\begin{array}{l}\text { Braimah(1984);Confirmed by enquiry } \\
(2020)\end{array}$ \\
\hline $\begin{array}{l}\begin{array}{l}\text { Public awareness of essence of } \\
\text { building approvals }\end{array} \\
\end{array}$ & Low & Adamolekun et al. ( 2017) \\
\hline $\begin{array}{l}\text { Public compliance with building } \\
\text { Laws }\end{array}$ & Low & $\begin{array}{l}\text { Ogeah and Omofonmwan (2013); Omuta } \\
\text { (1988) Adamolekun } \text { et al. (2017); } \\
\text { Omorotionmwan (2012); confirmed by } \\
\text { observation (2020) }\end{array}$ \\
\hline Effective Enforcement & Poor & $\begin{array}{l}\text { Ogeah and Omofonmwan (2013); } \\
\text { Adamolekun } \text { et al. (2017); Evbuomwan } \\
\text { as reported by Eweka (2017); } \\
\text { Omorotiomwan(2012) }\end{array}$ \\
\hline
\end{tabular}

Authors' Compilation, 2020

The most important issues in the table are that the city has no masterplan to guide its physical development. Thus there are no structure plans. There is a planning agency, but this is not adequately staffed and properly equipped. It is, therefore, unable to make an impact on monitoring, enforcement and in educating the public on planning laws. These assessments form the basis of the findings which are treated in the discussion section.

\subsection{Sustainable physical environments}

It was considered relevant to this study to undertake evaluations of the factors which have enabled the development of sustainable physical environments in other jurisdictions and the extent to which these factors feature in Benin City. Ever since the report of the UN World Commission on Environment and Development (1987) known otherwise as the Brundtland Report, the sustainable development discourse has permeated all aspects of human endeavour, but the environment remains the most critical aspect of the concept because it is base of human activities. Has planning been a factor in achieving a sustainable physical environment in other climes? As expressed by Keeble (1984), town planning ideally involves deciding what a city should look like before it is built. However, because most cities have grown of their own accord, planning usually concerns itself with deciding in which ways a city should remain as it is and in which ways it should be changed for the better. The nature of change required is not solely decided by the planner, but by society through the political process and the instrumentality of governance (Roberts, 1999) with the planner placing his expertise at the service of society. Through the planner and the planning process may decide the most appropriate choices for society and in the process restrain, constrain or coerce the individual in the interest of others (Roberts, 1999). The objective is to provide for urban dwellers the best possible standard for living and working by applying a process of continual improvement (Lohmann, 2006).Society's desires and expressed preferences are, therefore, critical to achieving a sustainable physical environment. A sustainable urban physical environment comes through environmentally responsible governance which creates a liveable space (New Zealand Ministry of the Environment, 2016). It is founded upon commitment: political commitment on the side of government, and social commitment or "buy-in", by the governed. This enables the creation of what is desired and the management of what is actually created. 


\subsection{Physical planning in Benin City and the City of London}

From the preceding, it should be clear that the fundamental issue in the development of a sustainable physical environment is planning governance which is supported by appropriate laws and equipped and empowered for performance. There are jurisdictions which have attained sustainable conditions by overcoming challenges such as faced by Benin City. An example is London City in the United Kingdom which has a history of "apparently unsuitable development, some very like those being experienced in today's most rapidly growing 'new' cities (Clark, 2015) having had a multi-century struggle for sustainable development (Clark, 2015). For these additional reasons, Benin City is compared with London City in terms of planning practice. First, London is an example of an environment where modern urban planning has been practiced for many decades. Secondly, it is chosen because it is an environmentally responsible city. Thirdly, although Benin has ancient origins, it is a relatively new city compared with London, considering that ancient Benin was burned down in 1897 and started its renaissance as a 1920 colonial township. London, on the other hand has evolved for over hundreds of years. British urban planning legislation and practice as well as research (Williams, 2014; Callies, n.d.) reveal some factors which are relevant to the sustainable development of cities These factors are listed in Table 3 as constituting the main requirements which make for effective physical planning. The items are seven in number starting from the availability of a plan. The other requirements relate to the implementation of the plan through appropriate laws made by society which presumably has a consensus on the desirability of planned development and the need to comply with the laws which drive the process.

Table 3: Instruments of physical planning: Benin City and London City

\begin{tabular}{|c|c|c|c|}
\hline $\begin{array}{l}\text { Prerequisites for effective } \\
\text { and sustainable physical } \\
\text { planning }\end{array}$ & Benin City & City of London & Evidence \\
\hline An urban plan & None available & Available & \multirow{8}{*}{$\begin{array}{l}\text { London is a leading world city } \\
\text { shaped by the British system of } \\
\text { land use planning and control } \\
\text { system which is among the } \\
\text { world's most sophisticated and } \\
\text { complex; has been experimenting } \\
\text { with comprehensive planning } \\
\text { laws since at least 1909; } \\
\text { permission for all private } \\
\text { development requires local } \\
\text { government permission (Callies, } \\
\text { n.d.); Much of the London's } \\
\text { urban form (in terms of settlement } \\
\text { patterns, street layouts and so on) } \\
\text { has been in place for hundreds of } \\
\text { years (Williams,2014); citizens } \\
\text { are compliant because planning } \\
\text { laws are understood and } \\
\text { enforcement effective. However, } \\
\text { has challenges of air quality \& } \\
\text { social cohesion (Clark, 2015) }\end{array}$} \\
\hline $\begin{array}{l}\text { An urban management } \\
\text { structure }\end{array}$ & Available, but weak & Firmly established & \\
\hline An urban management team & $\begin{array}{l}\text { Poorly established and } \\
\text { ineffective/Poor staffing by } \\
\text { professionals }\end{array}$ & $\begin{array}{l}\text { Firmly established } \\
\text { and effectively } \\
\text { managed by } \\
\text { professionals }\end{array}$ & \\
\hline $\begin{array}{l}\text { Work equipment for planning } \\
\text { administration }\end{array}$ & Poorly equipped & $\begin{array}{l}\text { Well-equipped and } \\
\text { professional }\end{array}$ & \\
\hline Appropriate legislation & Yes & Yes & \\
\hline Societal support & $\begin{array}{l}\text { Weak as evidenced by } \\
\text { illegal development }\end{array}$ & Strong & \\
\hline $\begin{array}{l}\text { Political consensus on } \\
\text { planned } \\
\text { development/planning } \\
\text { policy/ planning process }\end{array}$ & $\begin{array}{l}\text { Arguable. Existence of a } \\
\text { consensus is not reflected in } \\
\text { the state of the } \\
\text { environment/compliance } \\
\text { with planning laws }\end{array}$ & $\begin{array}{l}\text { Yes, long established } \\
\text { and widely accepted }\end{array}$ & \\
\hline $\begin{array}{l}\text { A highly enlightened } \\
\text { citizenry }\end{array}$ & $\begin{array}{l}\text { Low, as evidenced by low } \\
\text { awareness and compliance }\end{array}$ & $\begin{array}{l}\text { High, as evidenced } \\
\text { by high compliance } \\
\text { with planning laws }\end{array}$ & \\
\hline
\end{tabular}

Authors' Compilation, 2020

Table 3 shows that Benin City lacks effectiveness in many areas where London is fully established. The issues raised in this table form a part of the findings and come up in the discussion.

\subsection{Summary of findings}

The findings come from Table 1 which lists and classifies the urban physical problems Benin City; Table 2 which outlines and explains the state of physical planning in Benin City; and Table 3 which compares Benin City and London City in regard to the availability of the instruments of physical planning necessary for creating a sustainable environment. The results are as follows:

(1) Benin City lacks an urban masterplan.

(2) There is a low public awareness of the planning function in the city.

(3) The planning function is in a weak state, lacking the capacity for effective administration and enforcement. Planning was transferred from the town/city council to state authority in 1968. 
(4)There is now a fragmentation of urban governance between the state, on the one hand, and the four local government jurisdictions, on the other. This is a departure from the colonial practice of governance under a single authority.

(5) When compared with the City of London using the perquisites for effective and sustainable physical planning, Benin City suffers many deficiencies.

These findings are interwoven and they are considered in the discussion below.

\subsection{Discussion}

The lack of a master plan is unarguably a major challenge According to Braimah (1984), "the planning authorities, have failed in initiating master plans for urban centres in the state. So far, no urban centre in the State has a prepared and adopted master plan to serve as a guide to development control" (Braimah, 1984). This situation did not follow the promise represented by the British preparation of a survey plan for Benin Township. The designed township covered the present day Government Reservation Area (GRA) and the central part of the city. The GRA consisted of a residential area of 54 residential plots, set out in a grid-iron pattern crisscrossed by roads and an administrative area consisting of the High Courts, Prisons, Central Hospital, the Palace and Ring Road as well as the various roads which lead off this central point in a radial pattern (Aihie, 2015). This was evidence of physical planning in its original sense of deciding in advance what is to be built before it is built. Further evidence of planning is seen in the city's radial road network from the centre, the various quarters, Urubi, Oliha, Ogidan, Uselu and Eyaen and markets, and the establishment of three public cemeteries in different areas. There is also evidence of planning in the location of the aerodrome at the outskirts of town; the golf course; and planted trees along the township streets. The later establishment of a town council (later renamed city council to approve and monitor building development is also evidence of urban planning administration. The town was subject to the various colonial legislation on building lines, public sanitation and orderly development. There were three main legislations of the era - first the Nigerian Town and Country Planning Law of 1948 which provided "a legal, administrative and financial framework for physical planning schemes and the control of development" (Braimah, 1984); second, the Western Nigeria Planning law of 1969 which emphasised zoning and third, the Building Adoptive By-laws of 1960 for building control. It is correct to say that at independence in 1960, there had been established in the city a tradition of orderly physical development and public sanitation. The system was managed by town council engineers and sanitary inspectors. In 1959, the 1948 law was adopted for use in the Western Nigeria region of which Benin City was then a part. By the adoption of this law, three principles were emphasised: first, to make it possible for all land to be subjected to planning control by the planning authority; second, zoning for the separation of incompatible uses; and third, the allocation of future land use.

The absence of a master plan suggests that sub-optimal land use decisions have been taken over the years usually by private interests in pursuit of their own agenda. Uncontrolled, laissez faire spatial expansion at the periphery leads to a continuing loss of land cover as agricultural land is privately sub-divided and converted into development land without the input of the planner. As the environments thus created usually consist of only residential, commercial and industrial land uses, it has not been possible to have a land use pattern which reflects all urban land needs. This development of a non-rational pattern of land use (Aluko, 2011) is a characteristic of Nigeria's cities which has led Agboola and Agboola (1997) to assert that these spaces have grown in spite of the planning laws further leading to deficiencies in urban land management (Ikejiofor, 2009). Additionally, in the absence of a master plan, extant laws of planning such as zoning and development control have not been effectively managed. Omuta (1988) identifies weaknesses in administration and managerial capacity coupled with unplanned land use and uncontrolled physical development as being principally responsible for the state of city. Likewise, research by Ogeah and Omofonmwan (2013) also mention the role of poor planning enforcement capacity in the lack of separation amongst incompatible land uses and the congested nature of residential areas. Poor capacity in this case extends not only to the availability of equipment and personnel, but also, the effective implementation of the laws. This lack of capacity cuts across all aspects of planning.

Regarding zoning, residential, commercial and industrial areas were separated up till the 1970s. For instance, industrial activity such as sawmilling was not allowed in residential areas. This is not the case today. In these earlier years, physical development generally adhered to setbacks, but this is 
rarely the case today. Ogeah and Omofonmwan (2013) observe that the city had a relatively good environmental order up to the mid-1980s but the turn in the economy led to a deterioration as straitened circumstances led residential property owners to carry out conversions to non-residential (basically) commercial use. Such changes included the erection of kiosks, use of open spaces around buildings for workshops, building extensions and, in many cases, complete demolition and rebuilding with the common objective of either supplementing income or to create a new means of livelihood in the case of those who had lost theirs. Ogeah and Omofonmwan (2013) ascribe blame for these unpermitted changes to government, the defaulters, but also, the planning authority for not acting according to the 1992 law which provides for building plan approval before development can be done. Because the authors' survey revealed that only $36 \%$ of respondents were aware of the planning law, the planning authorities were found to be remiss in not educating the public aright.

Furthermore, since a master plan attempts to provide adequate space for all urban land needs, its absence implies that absence of a land use balance. A particular land use which is inadequately provided for in the present physical environment is open space (inclusive of green space and street trees). Research by Onwuanyi and Ndinwa (2017) established that there is a great dearth of open spaces in the city. There is a poor provision for green infrastructure, particularly street trees (Onwuanyi, 2020). A modern master plan is a sine qua non for planning, as a tool of urban management. Aspects of this plan may be reviewed periodically as required. The absence of a masterplan is compounded in Benin City by the absence of a practice of reviewing urban growth patterns and directing or redirecting them in the best interest of even development (Braimah, 1984).

Again, the poor situation of planning is also reflected in the level of compliance amongst the residents of the city. This has implications for the quality of the physical environment. Adamolekun et al. (2017) reveal that there is a low awareness of planning laws amongst the populace on setbacks, site coverage, zoning, parking and more. The authors attributing the finding to "a high level of poverty amongst the residents, a lack of awareness of regulatory standards and poor implementation on the part of the regulatory agency" (Adamolekun et al., 2017). In their Benin City study, Ogeah and Omofonmwan 2013) found that only $36 \%$ of respondents had an awareness of the planning laws. This is a challenge to compliance which compounds, and is compounded by, the challenge of official capacity. The effect is that enforcement cannot really be effective. In spite of the subsisting Edo State Urban Development Regulations of 2014, there have been chaotic developments such as "roof eavesextensions, structures erected on the right of way of roads/streets, the moat, river banks, under high tension cables of the electricity transmission company, attachments on wall fences, caravans, kiosks and wooden sheds which are scattered all over" (Omobude, 2019). This is because the machinery for administration and enforcement (professional planners, planning assistants, technical officers, organisational spread and equipment) are still inadequate. Furthermore, a senior government official, Dania, is reported by Eweka (2017), as admitting to a "problem of political interference" and a "lack of capacity in terms of adequate manpower and equipment", suggesting as solution "the political will to do the right thing".

Yet again, the transfer of the planning function from the town/city councils as it was before the 1970s to the state authority cannot really be seen as serving to make planning more effective. When Benin City became the capital of Mid-West region in 1963 following a plebiscite, the Benin City Council took charge of city administration and saw to physical development and environmental issues, using the structures and standards set in colonial times. This established system which was run by elected officials was interrupted by the 1966 political crisis which led to military rule starting in 1966 and subsisting until 1979 in the first instance. This was a precursor of change in governance and urban management. The 1967 military-induced geo-political restructuring of Nigeria led to the Mid-West region being re-designated as one of Nigeria's twelve new states. The change involved a shift of power at regional (now state) and federal levels from elected representatives to appointed military governors who operated outside the constitution. This also implied a shift in accountability. Rather than being from electorate to citizen, it shifted to the military and its high command. The 1976 second re-naming of the Mid-West State by military fiat as "Bendel" state was a reflection of the new ethos. In 1968, important environmental management functions of the Benin City Council were taken over by a new, military-created body known as the Bendel Development and Property Authority (BDPA). Thus, the Benin City Council ceased to be a planning authority. Being a state-wide agency, other town councils in the state such as Warri Township Council also ceased to function as planning authorities. 
Thus, urban planning and management for Benin City and the entire state became the sole responsibility of the agency. In this period, the city's population was far less than 400,000 persons. This view is supported by Doxiades Associates 1972 city population estimate of 201,000 (Doxiades Associates, 1972) and Sada's 1976 estimate of 314, 219 (Sada, 1976). Ikhuoria (1984) reveals that the city's spatial extent as at 1972 was $30 \mathrm{~km}^{2}$ or 3000 hectares whilst Odjugo et al. (2015) give an estimate of $359 \mathrm{~km}^{2}$ (35,900 hectares) as at 2013. This means that in the intervening years, the city had expanded over ten times in spatial extent. This was a good reason to evaluate the growth pattern of the city and its implications for orderly development in the years to come. However, the system in place was unable to discharge this responsibility.

The transfer of responsibility from council to state authority did not take into account the fact planning is a local activity. The effect of this reform was to centralise a function which was previously localised in the city councils. This might have made monitoring less effective, and therefore, increased the numbers of unplanned, unapproved and non-conforming development. The fact that the BDPA became defunct at a time and its functions taken over by the Military Governor's Office could have been contributed to the weakening of planning. It is important to recall that despite the existence of the Bendel Development and Planning Authority (BDPA) Order 1977 which was designed to be managed by the BDPA, planning functions were still being performed by the office of the military governor. In this connection Braimah (1987) states that: "since 1978, the Town Planning Division, currently part of the Military Governor's Office, has been entrusted the powers of the now defunct Bendel Development and Planning Authority, to control developments in the state. In addition, it possesses power to prepare land-use layouts and master plans, for declared planning areas" (Braimah, 1987). Thus, planning which should be a local activity was centrally managed in a topbottom manner. For instance, between 1967 and 1975, the military governor's office reconstructed and widened the city's major streets such as Mission Road, Forestry Road and Akpakpava Street and also established the BDPA and Aduwawa housing estates and built a stadium (1968) and university (1970). These important decisions were able to be taken by the governor's office because of the absence of elected officials. De jure and de facto, therefore, both city and state governance were responsibilities of the governor. Thus, the city's trajectory of growth and the quality of its management from the 1970 to 1990s were effectively set by successive unelected (military) officials who administered the state and the city and controlled all available resources. Then, as now, the case until that the state chief executive (the governor of Edo state) greatly influences the direction of the city's environmental policies and the pace at which they are implemented. Indeed, a parliament is in place, but it is a strong feature of the military-crafted 1999 constitution (now partially amended) that much power is placed in the office of the governor. This is evidenced by the 1979 Land Use Act (also a part of the constitution, which vests all land in urban areas in the office of the governor. The import of this provision can be appreciated from the essentiality of land to sustainable environmental development. The governor's exercise of his many powers tends to be the source of confrontations between the executive and legislature (Fatile, 2017). The situation is not helped by the apparent reluctance of state legislative assembles to exert their independence and perform oversight duties (Nwagwu, 2014).

The present fragmentation of city management into four local jurisdictions may not aid the effective development and management of the physical environment. Whilst physical planning is now a state responsibility, the local governments, as grassroots entities, need to be co-opted and involved in environmental management. This is particularly important since Area Planning Offices tend to be inadequate both in numbers and personnel (Braimah, 1988), giving room to haphazard land subdivision (Omuta, 1988). The existence of four local jurisdictions has the tendency to create an overlap not only between these four authorities, but between them and the state government which, as the constitutionally appointed supervisor of the former, is de facto and de jure manager of the city. UN (2012) emphasises thus: "urban governance is the hardware which enables the urban software to function ... to enable the local government response to the needs of citizens". This suggests that the capacity of cities to perform their developmental function and grow in a sustainable way depends on how well they are governed.

Lastly, a comparison of Benin City with the established jurisdiction of London City reveals that the former is deficient in many respects. Of course, the difference is that London has been exposed to modern planning interventions for a far longer time being the capital city of the UK where the Garden 
Cities Movement originated. London's poor environmental conditions in many decades past have been transformed. The city authority's commitment to doing better is expressed in the London Plan which presents a vision for sustainable development up to 2031. The aim is to make the city excel amongst global cities by achieving the highest environmental standards and quality of life whilst tackling urban challenges of the $21^{\text {st }}$ century, particularly climate change(Greater London Authority, 2011).The indicative features of sustainable physical development which are available in London City constitute lessons for Benin City if it desires also to achieve sustainable physical development.

In sum, the weak state of the planning function is a great threat to having a sustainable physical environment, particularly in the absence of a masterplan. This situation sustains the reign of laissez faire urban development, particularly at the periphery where most new development is taking place and where control is most needed. The direct causes of the present state of the physical environment are the lack of monitoring due to inadequate personnel and equipment; a failure to educate the public; to achieve a "buy in" to planning; and to implement sanctions, where necessary. Benin City is not truly characterised by modern practices in urban planning substantially because the urban physical form which was developed decades earlier when the population was far lower has not been reviewed to accommodate the changes made inevitable by population growth and urban sprawl. An inadequate response to the increase in the human and vehicular populations by expanding the road network, has brought about traffic congestions, rising air pollution from vehicular carbon emissions (Verere et al., 2015), sanitation and waste disposal challenges (Isah and Okojie, 2007), and of course, increased erosion and flooding events (Iyalomhe and Cirella, 2018). All of these affect sustainability of the physical environment.

\subsection{Conclusions}

This paper set out to evaluate the main challenges to achieving a sustainable physical environment in the modernising and urbanising space of Benin City. The study relied upon archival records and observation to identify and classify these challenges, outline and explain the state of physical planning in the city and evaluate the adequacy of the city's instruments of physical planning in relation to London which is established as a sustainable physical environment. The conclusion is that the weak state of planning governance in Benin City is a great threat to achieving a sustainable physical environment which is a requisite for sustainable development.

The findings are that Benin City lacks an urban masterplan. In addition, there is a low public awareness of the planning function. Furthermore, the planning function is in a weak state, lacking the capacity for administration and enforcement. Again, the planning function was transferred from the then sole city authority to the state government in 1968, but this has not manifestly strengthened it. Yet again, the city's governance was once under a single local authority, but is now fragmented amongst four and the state government. Lastly, a comparison of planning governance in Benin City with the established and sustainable City of London, reveals many important deficiencies on the part of the former which constitute barriers to achieving a sustainable physical environment.

The findings suggest that planning governance as currently constituted and practiced is not equipped to tackle the city's environmental challenges and deliver a sustainable physical environment. The present system may also create overlaps between the state government and the four city local governments on the one hand; and between the local governments, on the other. These may create ineffectiveness. Furthermore, the absence of a master plan is an indication that modern urban planning is not being practised in Benin City and this diminishes its capacity to respond to the demands of sound physical planning and management of the environment.

The study recommends production of a masterplan to guide the future development of the city. Furthermore, a stakeholder consensus built upon environmental responsibility is required, together with appropriate laws and empowerment of the planning function for good governance. Additionally, the engagement of numerically adequate planning personnel who must be well-trained and equipped for performance. Lastly, the commitment of officials at state and local levels to redirecting the city onto a trajectory of full compliance with the law and promotion of the ideals of sustainable development. 


\section{References}

Abdallah, T. (2017).Sustainable mass transit: Challenges and opportunities in urban public transportation. [online] Available at https://doi.org/10.1016/B978-012-811299-1.00001-0 Science Direct 1-14 [Accessed 17 March, 2021]

Adamolekun, M.O., Isiwele, A.J. and Akhimien, N.G. (2017).An assessment of the level of compliance with development control standards and housing policy in Nigeria: a case study of Esan West local government area of Edo State. https://openlearning.aauekpoma.edu.ng

Agboola, T. and Agboola, E.O. (1997). The development of urban and regional planning legislation and their impact on the morphology of Nigerian cities. The Nigerian Journal of Economic and Social Studies, 39(1) pp.123-144.

Aihie, E. (2015). The Benin City Pilgrimage Stations. Benin City: Aisien Publishers.

Aluko, O.E. (2011). Urbanization and effective town planning in Nigeria. African Research Review, 5(2) pp. 126-139.

Braimah, A.A. (1984). Town and country planning machinery in Bendel State, Nigeria. Third World Planning Review, 6(3) pp.255-261.

Braimah, A. A. (1987). Planning practice in Bendel State, Nigeria. Habitat International, 2(2), pp.1931.

Callies, D.I. (n.d.) Town and country planning in the United Kingdom. Environmental laws and their enforcement. Vol II Encyclopedia of Life Support Systems (EOLSS).http:// www.eolss.net/EolsssampleAllChapter.aspx.

Clark, W.C. (2015).London: A multi-century struggle for sustainable development in an urban environment. HKS Faculty Research Working Paper Series RWP15-047John F. Kennedy school of Government, Harvard University.

Doxiades Associates (1972). Nigeria: development problems and future needs of major urban centres, Doxiades Associates, Benin City.

Effiong, J. E. and Uzoezie, A.D. (2017). Increased paved surfaces as major factor of urban flooding in humid tropics: An example from Calabar, Cross River State, Nigeria. Presented at The 1st Geography and Environmental Science World Environmental Day Conference, University of Calabar on the 1st of June 2017.

Eweka, R. (2017, May19). Edo government holds workshop on urban and regional planning. Nigerian Observer. [online] Available at: www.nigerianobservernews.com (Accessed October 20, 2019).

Fatile, J.O. (2017). Legislative-executive relations and public policy formulation and implementation in Lagos state, Nigeria. OIDA International Journal of Sustainable Development, 10(6), pp. 1-12.

Greater London Authority (2011).The London plan: Spatial development strategy for Greater London, July 2011.Greater London Authority.

Healthy Parks Healthy People (2015).Urban planning and the importance of green space in cities to human and environmental health.www.hphpcentral.com.

Ikejiofor, U.C. (2009).Planning within the context of informality: issues and trends in land delivery in Enugu, Nigeria. Case study prepared for revisiting urban planning: Global Report on Human Settlements 2009.1-22 Available from http//www.unhabitat.org/grhs/2009. (Accessed 2 February, 2019).

Ikhuoria, I.A. (1984). Rapid urban growth and urban land use patterns in Benin City, Nigeria. University of Benin, Nigeria (Mimeo). 
Isah, E.C. and Okojie, O.H. (2007). Environmental sanitation in an urban community in Benin City. The Nigeria Postgraduate Medical College Journal, 14(1), pp. 12-15.

Iyalomhe, F. and Cirella, G.T. (2018). Flooding in Benin City, Nigeria. Krakow, Poland 2nd International Conference on Sustainability, Human Geography and Environment 2018 (ICSHGE18).

Keeble, L. (1982). Town Planning Made Plain. Construction Press, London

Lohmann, K.B. (2006). Principles of City Planning. McGraw Hill, New York

MIT (2000).What are key urban environmental problems? Understanding Issues [online] Extracted from DANIDA Workshop Papers: Improving the Urban Environment and Reducing Poverty, December 5, 2000, Copenhagen, Denmark. Available at http://web.mit.edu/urban upgrading/urban environment/issues/key-UE-issues.html. [Accessed 19 March, 2021].

New Zealand Ministry for the Environment (2016). Attributes of successful towns and cities [online] Available at: http://www.mfe.govt.nz/publications/towns-and-cities [Accessed 17 July, 2019].

Nwagwu, E.J. (2014).Legislative oversight in Nigeria: A watch dog or a hunting Dog? Journal of Law, Policy and Globalisation. 22. www.iiste.org

Odjugo, P.A.O., Enarubve, G.O. and Isibor, H.O. (2015).Geo-spatial approach to spatio-temporal pattern of urban growth in Benin City, African Journal of Environmental Science and Technology, 9(3), pp.166-175.

Ogeah, F.N. and Omofonmwan, S.I. (2013).Creation and demolition of illegal structures in Nigerian cities. Jorind 11(1) pp. 270-270., Available at: www.transcampus.org (Accessed October 27, 2019).

Omobude, T. (2019, April 9).Edo government to demolish illegal structures in Benin City. [online] Factsreportersng. Available at http://www.factsreportersng.blogspot.com [Accessed October 20, 2019].

Omorotiomwan, J. (2012, December 27). We were asleep while they built. Vanguard [online] Available at: http://www.vanguardnews.com (Accessed July 17, 2018).

Omuta, G.E.D. (1988).Environmental planning, administration and management in Nigerian cities: The example of Benin City, Bendel State. Public Administration and Development, 8(1), pp. 1-14.

Onwuanyi, N. and Ndinwa, C.E (2017). Remaking Nigeria's urbanism: Assessing and redressing the dearth of open spaces in Benin City. International Journal of Built Environment and Sustainability, 4(2), pp.121-130.

Onwuanyi, N. (2020).Deficiency of street trees in Benin City: A survey of residents' perceptions, pp. 1-14 in Land Use Management and Environmental Sustainability in Nigeria edited by V. Umoren and \& J. Aster (Eds.), University of Uyo, Nigeria. ISBN: 978-978-57832-0-9.

Roberts, M. (1999). An Introduction to Town Planning Techniques. UCL Press. London

Sada, P.O. (1984). Urbanisation and living conditions in Nigerian cities. Research Triangle Institute, North Carolina.

Sharifi, A. (2016). From garden city to eco-urbanism: the quest for sustainable neighborhood development. Sustainable Cities and Society, 20, pp. 1-16 [Accessed 1 June, 2018]

Report of the UN world commission on environment and development (1987). Our Common Future, www.un-document.net.our-common-future. 
UN (2012).Governance [online]. Available at: http://unhabitat.org/governance. [Accessed 23 February, 2021].

United Nations (2015).Sustainable development goals.

Verere, S.B., Oluwagbenga, O., and Orimoogunje, I. (2015).Geo-spatial mapping of air pollution in Benin City, Nigeria. Journal of Geography, Environment and Earth Science International, 3, pp. 1-17 [Accessed 30 September, 2016].

Williams, K. (2014). Urban form and infrastructure: A morphological review. Government Office for Science. The UK Government's Foresight Future of Cities Project.

\section{Cite this article as:}

Onwuanyi, N. and Ojo, E. P. 2021. Evaluating the Main Challenges to a Sustainable Physical Environment in Benin City. Nigerian Journal of Environmental Sciences and Technology, 5(1), pp. 222-233. https://doi.org/10.36263/nijest.2021.01.0268 